\title{
Chromosomal basis for a bilateral gynandromorph in Pycnogaster inermis (Rambur, 1838) (Orthoptera, Tettigoniidae)
}

\author{
P. Barranco ${ }^{1}$, J. Cabrero' 2 J.P.M. Camacho ${ }^{2} \&$ F. Pascual $^{3}$ \\ ${ }^{1}$ Departamento de Biología Aplicada, Escuela Politécnica Superior, Universidad de Almería, \\ E-04120 La Cañada, Almería, Spain; ${ }^{2}$ Departamento de Genética, Facultad de Ciencias, Universidad de \\ Granada, E-18071 Granada, Spain; ${ }^{3}$ Departamento de Biología Animal y Ecología, Facultad de \\ Ciencias, Universidad de Granada, E-18071 Granada, Spain
}

Keywords: Gynandromorphism, cytogenetics, Pycnogaster inermis, Tettigoniidae, Orthoptera

\begin{abstract}
Morphological and cytogenetic analyses of a spontaneous gynandromorph of Pycnogaster inermis, found in a natural population in the Spanish Sierra Nevada, have shown that the left side was male and the right side female, with almost perfect bilateral symmetry. Ventral valves of the ovipositor were very short, appearing as two spurs; dorsal valves were longer but still shorter than normal. The specimen had an apparently normal testis on the left side and a well-developed ovary on the right side.

Cytogenetic analysis revealed the presence of $2 n=28+X 0$ chromosomes in the testis and $2 n=28+X X$ in the ovary, the same as standard males and females, respectively, of this species. This suggests that the gynandromorphism occurred at a very early developmental stage. This gynandromorph could have originated from the formation of a binucleate egg by second-polar-body reactivation and subsequent fertilization by two spermatozoa, one male- and the other female-determining; however, the most parsimonious explanation is the elimination of one $\mathrm{X}$ chromosome in a female-determined zygote $(\mathrm{XX})$ at the first cleavage division.
\end{abstract}

\section{Resumen}

Los análisis morfológicos y citogenéticos de un espécimen ginandromórfico de Pycnogaster inermis encontrado en una población natural de Sierra Nevada mostraron que el lado izquierdo era macho y el lado derecho hembra, con una simetría bilateral casi perfecta. Las valvas dorsales del oviscapto eran más cortas que las de una hembra normal mientras que las ventrales eran muy cortas, casi como espolones. Internamente había un testículo aparentemente normal en el lado izquierdo y un ovario bien desarrollado en el lado derecho.

El análisis citogenético reveló la presencia de $2 \mathrm{n}=28+\mathrm{X} 0$ cromosomas en el testículo y de $2 n=28+X X$ en el ovario, lo mismo que en los individuos normales de la especie. Esto sugiere que el ginandromorfismo se generó en un estadío muy temprano del desarrollo. El origen de este ginandromorfo pudo estar basado en la formación de un óvulo binucleado por reactivación del segundo corpúsculo polar y fertilización subsiguiente de éste por dos espermatozoides, uno masculino y otro femenino; pero la explicación más simple es la eliminación de un cromosoma $\mathrm{X}$ en un cigoto hembra $(\mathrm{XX})$ en la primera división de la segmentación.

\section{Introduction}

Gynandromorphism is a relatively common phenomenon among insects (Crew, 1965) and has been reported in many different groups including the Orthoptera. Chopard (1938), Uvarov (1966), and Hewitt (1979) have published comprehensive reviews on gynandromorphism in Orthoptera. In most cases, the report was limited to a study of external morphology, genitalia, and sometimes internal organs. Hewitt (1979) reviewed over 100 gynandromorphs reported in Orthoptera, about one quarter of which had been found in Tettigonioidea. As he noted, only a few cases have received a full examination including chromosome analysis of male and female tissues. Most gynandromorphs show bilateral symmetry, one half being male and the other female, although several patterns showing predominance of one sex over the other have also been described (Hewitt, 1979). Differing patterns of gynandromorphism are feasible in insects because the sex is determined in each cell individually, so that the genetic constitution of 

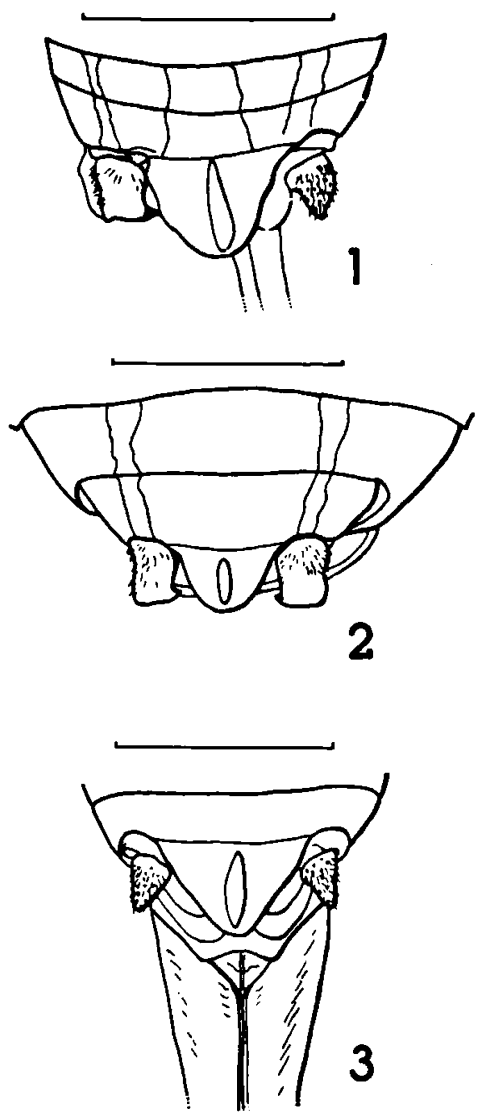

Figs. 1-3. Posterior part of the abdomen (dorsal view) of (1) the gynandromorph, (2) a normal male and (3) a normal female. Scale bar $=0.5 \mathrm{~cm}$.

each cell determines its own phenotypic expression for sex. The predominant chromosomal sex-determination mechanism in Orthoptera is the $\mathrm{X0} 0^{\circ} /$ XX o system (White, 1973).

Of the several cytogenetic theories advanced to explain bilateral gynandromorphism, two apply best to Orthoptera: (1) a binucleate egg is produced by the failure of the second meiotic division and, subsequently, one of the nuclei is fertilized by an $\mathrm{X}$ sperm and the other by an 0 sperm; and (2) one of the $\mathrm{X}$ chromosomes in an $\mathrm{XX}$ zygote is eliminated at the first cleavage division. To distinguish accurately between these two hypotheses, genetic markers are essential. Such markers have shown that the second mechanism is the more frequent one in Drosophila, and that the proportion of male and female tissues in the adult gynandromorph depends on the moment at which the $\mathrm{X}$ chromosome is lost (Lawrence, 1992). Thus, if one $X$ chromosome is lost during the second cleavage division, or afterwards, a clear predominance of female over male tissues will follow. On the other hand, the predominance of male tissues, reported in some acridoids (see Hewitt, 1979), could easily be explained by non-disjunction of the single $\mathrm{X}$ chromosome of a male zygote, in a stage from the second cleavage division onwards, giving rise to a proportion of $\mathrm{XX}$ cells lower than $50 \%$.

In Orthoptera, the only reported case with a genetic marker (which produced a colour mosaicism), provided evidence for the binucleate egg mechanism in the grasshopper Valanga irregularis (Walker, 1870) (cf. White, 1968). The present paper deals with a spontaneous gynandromorph of the tettigonid species Pycnogaster inermis (Rambur, 1838). Morphological and cytogenetic analyses have shown that this specimen was an almost perfect bilateral gynandromorph, with no predominance of one sex over the other, and that primary spermatocytes in the testis were $\mathrm{X} 0$, but ovariolewall cells were XX. Hypotheses to explain the origin of this specimen are discussed.

\section{Materials and methods}

One male, one female, and one gynandromorph of Pycnogaster inermis were collected at Morrón del Chullo (Sierra Nevada, Huéneja, Granada, Spain) at $2280 \mathrm{~m}$ altitude; UTM coordinates: 30SWG0206. After a detailed examination of external morphology, the individuals were anaesthesized and dissected for a thorough study of internal anatomy, after which the gonads were fixed for cytological analysis. For this purpose, the female and the gynandromorph were injected, in the abdomen, with $0.05 \%$ colchicine in insect saline solution $6 \mathrm{~h}$ prior to dissection. The gonads were then immersed into 3:1 ethanol:acetic acid and stored in a refrigerator at $4^{\circ} \mathrm{C}$. For cytological analysis, preparations were made by squashing the different materials in acetic orcein. To perform the $\mathbf{C}$-banding technique, squashing was done in $45 \%$ acetic acid and the coverslip was removed after immersing the preparation in liquid nitrogen. The $\mathrm{C}$-banding was performed following the technique described in Camacho et al. (1984). 


\section{Results}

\section{Morphological analysis}

The general appearance (colour, size, and shape) of the gynandromorph was rather similar to that of normal specimens of this species, but the external genitalia and abdominal sternites were clearly different (Figs. 1-6). Neither male nor female features predominated. The dorsal terminal abdominal structures were well formed, but the ventral ones were equally amorphous in both sex halves. The gynandromorph showed a body size similar to that of a normal male, but the pronotum was more characteristic of females. Tegmina venation was similar to that in females, but the internal edge of the left tegmen was sinuous as that of males. Abdominal sternites showed a superficial and irregular suture closed in the middle (Fig. 4).

Male features. - External male features were apparent on the left side of the gynandromorph. The specimen had a properly situated normal male cercus, but the epiproct was wider than normal (Figs. 1-2). The soft structures of the male genitalia were conspicuous, hiding a single titillator. Although completely sclerotized the titillator was small, flat and with a rounded apex. The subgenital plate was deformed, reduced and slightly displaced outside the body (Fig. 4).

There was an apparently normal testis in the internal left side. Regarding the accessory glands, the seminal vesicles were well developed and located on the left side and extended under the ovary, which was situated on the right body half. The ductus ejaculatorius was not interconnected with the oviduct.

Female features. - The specimen had developed the external female features on its right side. The female cercus was normal and normally positioned (cf. Figs. 1 and 3). Ventral structures, however, were quite modified. The female subgenital plate was reduced to a highly sclerotized lateral lobe and a small rough amorphous callus situated close to the left ventral valve (Fig. 4). The ovipositor had four deformed valves of different sizes. The ventral valves, extremely short, were reduced to two spurs. Dorsal valves were longer, the right one being
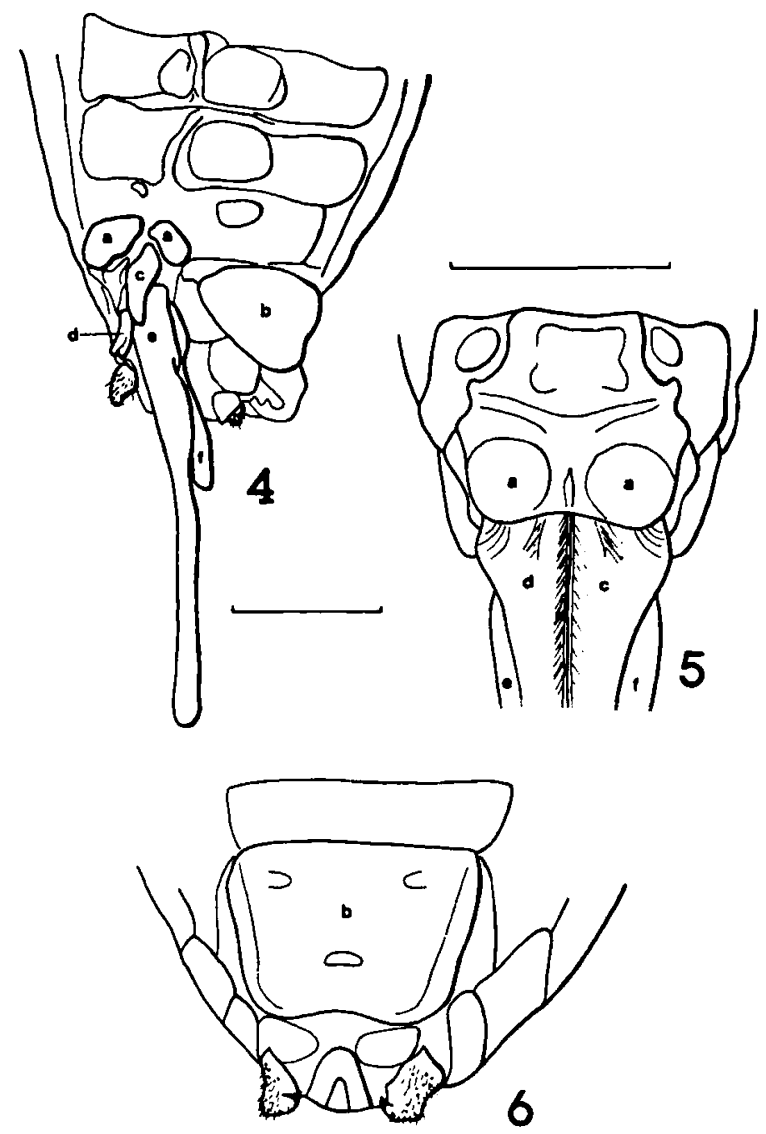

Figs. 4-6. Posterior part of the abdomen (ventral view) of (4) the gynandromorph, (5) a normal female and (6) a normal male ( $a=$ sclerites of the female subgenital plate, $b=$ sclerite of the male subgenital plate, $c=$ left ventral valve, $d=$ right ventral valve, $e=$ right dorsal valve, $f=$ left dorsal valve). Scale bar $=0.5 \mathrm{~cm}$.

smaller than a normal one and showing a rounded apex, and the left dorsal valve being slightly twisted and measuring half the length of the right dorsal valve (Figs. 4-6).

On the internal right body half there was a welldeveloped ovary full of eggs at different maturation stages. The oviduct and the spermatheca were apparently normal.

\section{Cytological analysis}

Conventional staining with acetic orcein showed that ovariole-wall cells analyzed from the ovary, 


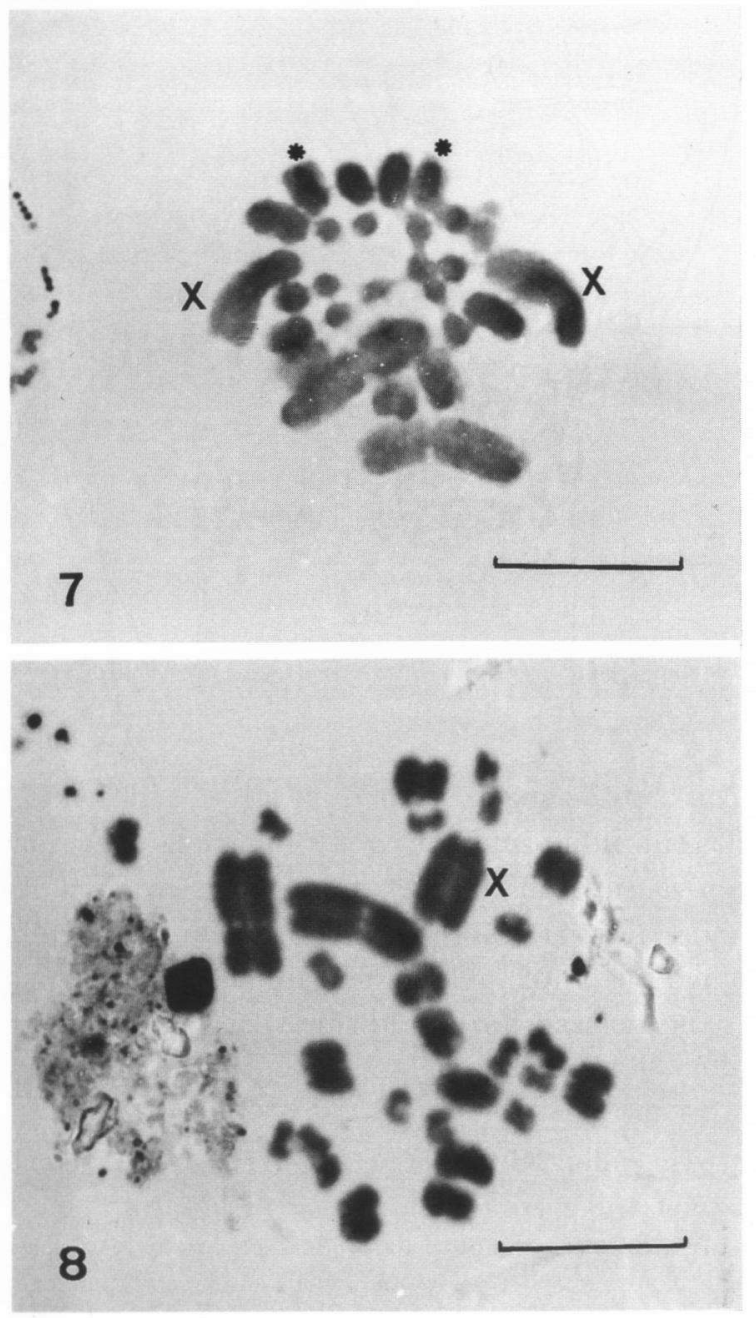

Figs. 7-8. Mitotic metaphase cells showing $2 \mathrm{n}=28+\mathrm{XX}$ chromosomes in the ovary located on the right side of the gynandromorph (Fig. 7) and $2 \mathrm{n}=28+\mathrm{X0}$ chromosomes in the testis located on the left side of the body (Fig. 8). Asterisks indicate overlapping of two chromosomes. Scale bar $=5 \mu \mathrm{m}$.

situated on the right side of the gynandromorph's body, showed the typical female chromosome number, $2 n=28+X X$ (Fig. 7), and the testis located on the left half possessed $2 n=28+X 0$ chromosomes (Fig. 8), as in the testes of a normal male. This chromosome number coincides with that reported by Sentís et al. (1988). Thus, the sexual differences showed by the two longitudinally defined halves of the gynandromorph had a chromosomal basis, the female half possessing two $\mathrm{X}$ chromosomes and the male half showing only one.
The application of C-banding to test for any heterochromatin polymorphism, that could help in determining the exact origin of this gynandromorphism, provided no additional information, no variations in the C-banding pattern being observed, neither in the gynandromorph nor in the two normal individuals.

\section{Discussion}

The fact that the bilateral gynandromorphism of the specimen analyzed was almost perfect indicates that the developmental anomaly occurred very early in ontogeny. The two most likely explanations are: (1) derivation from a binucleate egg resulting from second polar body activation, which was fertilized by two spermatozoa, one with an X chromosome and the other without, and (2) loss of one of the two $\mathrm{X}$ chromosomes in a female zygote, occurring in one of the cells resulting from the first cleavage division. The first mechanism could explain bilateral gynandromorphy as that reported by White (1968).

Although the hypothesis of a binucleate egg cannot be ruled out in the $P$. inermis gynandromorph reported here, the simplest explanation is that an $\mathrm{XX}$ zygote lost one of the $\mathrm{X}$ chromosomes in one of the two cells resulting from the first cleavage division. The distinction between these two possibilities would be easy in XY $\sigma / \mathrm{XX}$ \% organisms because, as cytological analysis would show, the male part in a gynandromorph produced by an X elimination would be $\mathrm{X} 0$ instead of $\mathrm{XY}$. In X0 o / XX \% organisms, as in fact most orthopterans are, cytological study does not distinguish between the binucleate egg and X-elimination hypotheses, for which purpose genetic markers are indispensable. We have tried to obtain cytogenetic markers by means of C-banding, but were unsuccessful.

Despite the large number of gynandromorphs reported in Orthoptera, only a few were cytologically analyzed (Hewitt, 1979). In tettigoniids, this analysis has been made by Pearson (1929) in only two partial gynandromorphs, Amblycorypha rotundifolia (Scudder, 1862) and $A$. oblongifolia (De Geer, 1773). In these cases, as in $P$. inermis, the 
ovarian tissue showed two $\mathrm{X}$ chromosomes and the testicular tissue had a single $X$.

It has been clearly established that the first cleavage division determines bilateral symmetry of the embryo (Houillon, 1972). In some organisms, such as Drosophila, the first plane of cleavage is random and the nuclei do not completely mix as they divide, resulting in large and well-separated male and female territories in the gynandromorphs (Lawrence, 1992). A test of this feature in Orthoptera could be the analysis of the tendency to become male or female for each half of bilateral gynandromorphs. In tettigoniids, Hewitt (1979) reviewed four cases, in two of which the left half was male and, in the other two, female. Furthermore, Mateos \& Peinado (1986) reported a case in Platycleis intermedia (Serville, 1839) in which the left half was female. In the present $\boldsymbol{P}$. inermis bilateral gynandromorph, the left half was male, giving a balanced (3:3) number of left- and right-side female cases, as would be expected from a random first cleavage. In Acridoidea, however, the right side is always female (Hewitt, 1979). The different patterns shown by these two orthopteran groups could be due to differences in the period encompassed by the meiotic divisions of the egg and first cleavage division of the embryo (Hewitt, 1979).

\section{Acknowledgements}

We would like to thank Lola Campos-Carmona for her help during the collection of the samples among which this gynandromorph was found, and two anonymous referees for their perceptive criticism. This study was supported by grants from the
Spanish D.G.I.C.Y.T. (PB93-1108) and the Plan Andaluz de Investigación (Grupos no. 3122 and 4068).

\section{References}

Camacho, J.P.M., E. Viseras, J. Navas \& J. Cabrero, 1984. Cheterochromatin content of supernumerary chromosome segments of grasshoppers: detection of an euchromatic extra segment. Heredity, 53: 167-175.

Chopard, L., 1938. La biologie des Orthoptères: 1-291 (Le Chevalier, Paris).

Crew, F.A.E., 1965. Sex-determination (4th ed., revised): 1-188 (Methuen \& Co., London).

Hewitt, G.M., 1979. Grasshoppers and crickets. In: Animal cytogenetics 3: Insecta 1 Orthoptera: 1-170 (Gebrüder Borntraeger, Berlin/Stuttgart).

Houillon, Ch., 1972. Embriología: 1-184 (Ediciones Omega, Barcelona).

Lawrence, P.A., 1992. The making of a fly: 1-228 (Blackwell Scientific Publications, Oxford).

Mateos Martín, J. \& M.V. Peinado de Diego, 1986. Un Platycleis intermedia (Serv.) ginandromórfico (Orthoptera, Tettigoniidae). Actas VIII Jornadas Asociación Española de Entomología: 335-341 (Universidad de Sevilla, Sevilla).

Pearson, N.E., 1929. The structure and chromosomes of three gynandromorphic katydids (Amblycorypha). J. Morph., 47: 531-553.

Sentis, C., J. Santos \& J. Fernández-Piqueras, 1988. Primary and secondary nucleolar organiser regions during spermatogenesis in the genus Pycnogaster. Heredity, 60: 197-204.

Uvarov, B.P., 1966. Grasshoppers and locusts I: 1-481 (Cambridge University Press, Cambridge).

White, M.J.D., 1968. A gynandromorphic grasshopper produced by double fertilization. Aust. J. Zool., 16: 101-109.

White, M.J.D., 1973. Animal cytology and evolution (3rd ed.): 1-961 (Cambridge University Press, London).

Received: 27 July 1994 